\title{
心房細動の病態と治療の進歩
}

\section{2. ヒト心房活動電位モデルを用いた各種 $\mathrm{I}_{\mathrm{Kr}}$ 遮断薬と

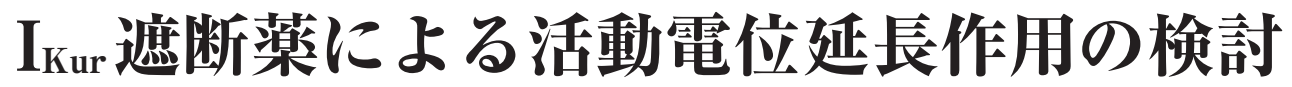

\author{
村上慎吾*1, 2 辻前賢司*1,3 鈴木慎悟*1, 4 倉智嘉久*1, 2
}

心房細動 (AF) に対する抗不整脈薬の有効な薬物像を探るためにヒト心房活動電位モデルを用い, 遅延 整流 $\mathrm{K}^{+}$電流の速い成分 $\left(\mathrm{I}_{\mathrm{Kr}}\right)$ の遮断薬と非常に速い活性化過程をもつ遅延整流 $\mathrm{K}^{+}$電流 $\left(\mathrm{I}_{\mathrm{Kur}}\right)$ の遮断薬の遮断 様式が, どのように心房の活動電位延長作用に対して影響をもつかを考察した. まず最初に, 三つの薬物 (ドフェチリド, キニジン, ベスナリノン)の特徵的な $I_{\mathrm{k}}$ 遮断様式がもつ心房活動電位延長作用の刺激頻 度依存性について, Courtemancheらによるヒト心房活動電位モデルを用いて検討を行なつた，才リジ ナルのモデルの遅延整流 $\mathrm{K}^{+}$電流の遅い成分 $\left(\mathrm{I}_{\mathrm{Ks}}\right)$ に遅い活性化成分を導入すると, ドフェチリド，キニジ ンの逆頻度依存性が再現された。また, ベスナリノンは明確な逆頻度依存性を示さず, 実験結果と一致

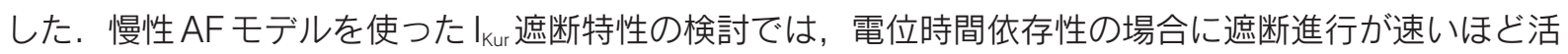
動電位延長作用が強くなり, 活動電位延長作用は遮断様式に依存した。実験での薬物効果の確認では短 いテストパルスが必要とわかり，薬物作用の検討にモデルの使用が有効であることが示された.

(心電図, $2009 ； 29 ： 126$ ～132)

I .はじめに

心房細動 $(\mathrm{AF})$ が発生すると，心房内で血液が滞 留し, 血栓が生じて, 重篤な脳梗塞を引き起こす。 また，心不全重症度との関連も指摘され，年齢とと

\begin{tabular}{|c|c|}
\hline Keywords & $\begin{array}{l}\text { • 心房細動 } \\
\text { •抗不整脈薬 } \\
\text { ・シミュレーション } \\
\text { ・ } \mathrm{I}_{\mathrm{Kr}} \\
\text { • } \mathrm{I}_{\mathrm{Kur}}\end{array}$ \\
\hline
\end{tabular}

*1大阪大学大学院医学系研究科薬理学講座 (分子 - 細胞薬理学)

( ₹ 565-0871 大阪府吹田市山田丘 2-2)

$* 2$ 大阪大学臨床医工学融合研究教育センター

$* 3$ 大塚製薬株式会社探索第一研究所

*4国立循環器病センター
もに有病率も高まるため, AFは我が国のような高 齢化社会において重点的な対策を要する疾患であ る。しかし， $\mathrm{AF} の$ 治療を目的とした既存の抗不整 脈薬はその心室に対する副作用のため, 使用に制限 が設けられている。 そのため, AFの治療には, 従 来と異なる機序の, 重大な副作用をもたない新たな 抗不整脈薬が必要とされている。

今回の報告では，新たな抗不整脈薬の機序を探る ため, シミュレーションにより遅延整流 $\mathrm{K}^{+}$電流の速 い成分 $\left(\mathrm{I}_{\mathrm{Kr}}\right.$; rapidly activating $\mathrm{K}^{+}$current)の遮断 薬と非常に速い活性化過程をもつ遅延整流 $\mathrm{K}^{+}$電流 ( $\mathrm{I}_{\mathrm{Kur}}$; ultra-rapidly activating $\mathrm{K}^{+}$current)の遮断 薬の理想的な特性を探った. 前半では, 発現系で計

Recent advances in the research and treatment of atrial fibrillation In silico study on the effects of $I_{k r}$ and $I_{k u r}$ block kinetics on prolongation of human action potential Shingo Murakami, Kenji Tsujimae, Shingo Suzuki, Yoshihisa Kurachi 


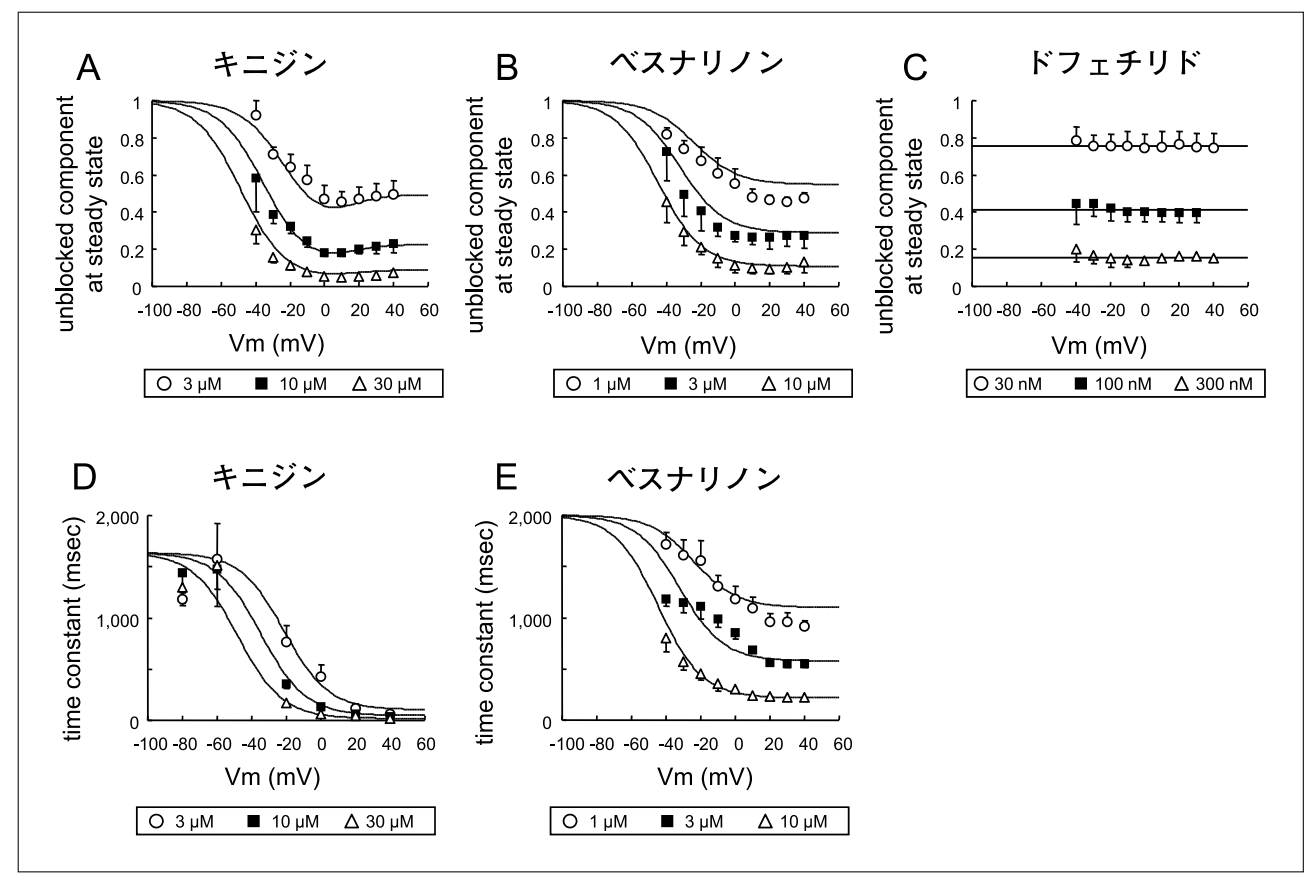

図1 電位時間依存性 $I_{\mathrm{kr}}$ 遮断のモデル化

キニジン $(\mathrm{A}, \mathrm{D})$ ，ベスナリノン $(\mathrm{B}, \mathrm{E})$ ，ドフェチリド $(\mathrm{C})$ の電位 $(\mathrm{A}-\mathrm{C})$ と時間 (D-E) に依存した $\mathrm{I}_{\mathrm{Kr}}$ 遮断. シンボルは文献3) と文献4)からの実験結果, 実線は今回作成したモデルによる計算結果.

〔文献1)より引用改変〕

測したドフェチリド，キニジン，ベスナリノンの $\mathrm{I}_{\mathrm{Kr}}$ 遮断特性をモデル化し，ヒト心房筋細胞モデルに適 用することで， $\mathrm{I}_{\mathrm{Kr}}$ 遮断特性の違いが活動電位延長作 用の頻度依存性にどのように影響を与えるかを考察 した ${ }^{1)}$. 後半では，近年 AFを対象とした抗不整脈薬 の機序として注目を集めている $\mathrm{I}_{\mathrm{Kur}}$ 遮断薬の理想的 な特性の考察を行った ${ }^{2)}$.

\section{II . $\mathrm{I}_{\mathrm{kr}}$ 遮断薬による活動電位延長}

遅延整流性 $\mathrm{K}^{+}$電流は活動電位の 2 相, 3 相に寄与 し，活動電位長を制御することが知られている．特 に $\mathrm{I}_{\mathrm{Kr}}$ と遅延整流 $\mathrm{K}^{+}$電流の遅い成分 $\left(\mathrm{I}_{\mathrm{Ks}}\right.$; slowly activating $\mathrm{K}^{+}$current) は遅延整流性 $\mathrm{K}^{+}$電流の主な 構成成分であり，ヒトを含む様々な哺乳類の心臓に 存在する．多数の薬物が $\mathrm{I}_{\mathrm{Kr}}$ を遮断することで, $\mathrm{QT}$ 間隔を延長し，torsades de pointes (TdP) を含む不 整脈を誘発することが知られている． $\mathrm{I}_{\mathrm{Kr}}$ を選択的に 遮断するドフェチリドやE-4031のような薬物は徐脈
時に活動電位を大きく延長する。この特性は逆頻度 依存性とよばれ，徐脈時の過度の活動電位延長と $\mathrm{TdP}$ を誘発する原因になると考えられており，薬物 における催不整脈特性の指標の一つとされている. ドフェチリドやE-4031 は電位時間非依存的に $\mathrm{I}_{\mathrm{Kr}}$ を遮 断する.われわれは, 以前の研究でIa群のキニジン や強心剤のベスナリノンが，発現系での HERG (human ether-a-go-go) 電流を電位時間依存的に遮断 することを明らかにした ${ }^{3)}{ }^{4)}$ 。その結果， $\mathrm{I}_{\mathrm{Kr}}$ 遮断薬 は少なくとも三つの分類，(1)電位時間非依存性 $\mathrm{I}_{\mathrm{Kr}}$ 遮断〔(例) ドフェチリド，E4031〕，(2速い電位時間 依存性 $\mathrm{I}_{\mathrm{Kr}}$ 遮断〔(例 $)$ キニジン〕，(3)遅い電位時間依 存性 $\mathrm{I}_{\mathrm{Kr}}$ 遮断〔(例)ベスナリノン〕に分けられること がわかった(図1参照)。キニジンとべスナリノンは ともに細胞膜電位が脱分極するほど $\mathrm{I}_{\mathrm{Kr}}$ を強く遮断す るが， $\mathrm{I}_{\mathrm{Kr}}$ 遮断の進行についてはキニジンのほうが速 いことがわかった(図1D，E)。ドフェチリドとキニ ジンは逆頻度依存性をもつ，ベスナリノンはもたな 
い，ドフェチリドとキニジンは TdPを起こすという 報告があるが，ベスナリノンにはいずれの報告もな い，などの背景にこのような薬物動態の違いが存在 する可能性がある.

選択的 $\mathrm{I}_{\mathrm{Kr}}$ 遮断薬であるドフェチリドは $\mathrm{AF}$ を適応 疾患として米国で承認されており，そのような観点 から，心房における $\mathrm{I}_{\mathrm{Kr}}$ 遮断薬の作用特性は重要であ ると考えられる。そこでわれわれは，前述の三つの $\mathrm{I}_{\mathrm{Kr}}$ 遮断薬による異なる作用特性をヒト心房モデルに 導入し， $\mathrm{I}_{\mathrm{Kr}}$ 遮断薬ごとに異なる活動電位延長作用と 逆頻度依存性の機序を考察した。

まず最初に，Courtemancheらによるヒト心房筋 細胞モデル ${ }^{5}$ の $\mathrm{I}_{\mathrm{Ks}}$ に遅い活性化成分を導入し，ドフェ チリドによる逆頻度依存性を再現できるようにし た。このヒト心房筋細胞モデルは，膜容量，膜抵抗 などの電気的特性や，Hodgkin-Huxley 型の方程式 によって計算される 12 種のイオン電流 $\left(\mathrm{I}_{\mathrm{Na}}, \mathrm{I}_{\mathrm{K} 1}, \mathrm{I}_{\mathrm{t}}\right.$, $\left.I_{\text {Kur }}, I_{\text {Kr }}, I_{K s}, I_{\text {Ca, L }}, I_{p, C a}, I_{\text {NaK }}, I_{\text {NaCa }}, I_{b, ~ N a}, I_{b, ~ C a}\right) に よ$ り構成される。さらに，以前の研究で明らかにした ドフェチリド，キニジン，ベスナリノンの実験デー 夕 3), 4)から，ドフェチリド型，キニジン型，ベスナ リノン型の $I_{K r}$ 遮断モデルを作成した (図1, 実線). 電位時間非依存性の遮断についてはドフェチリド型 と名づけ(図 1C), この研究では $10 \%$ まで電流量を 遮断した． $\mathrm{I}_{\mathrm{Ks}}$ 電流モデルに遅い活性化成分を導入す ると，実験的な知見と同様にドフェチリド型の $\mathrm{I}_{\mathrm{Kr}}$ 遮 断により活動電位延長は逆頻度依存性を示した (図2)。一方，電位時間依存性遮断を示すキニジン 型，ドフェチリド型 $\mathrm{I}_{\mathrm{Kr}}$ 遮断モデルでシミュレーショ ンを行ったところ，実験結果と同様に，キニジン型 は逆頻度依存性を示したが，ベスナリノン型は明確 な逆頻度依存性を示さなかった。

次に，逆頻度依存性が異なる機序の解析を行った (図 3). 静止電位や活動電位の大きさに影響を与え ることなく，刺激周期が $500 \mathrm{msec} ， 1,000 \mathrm{msec}$, $1,500 \mathrm{msec}$ いずれの場合でも全ての薬物型 $\mathrm{I}_{\mathrm{Kr}}$ 遮断で 活動電位が延長した。刺激周期が長くなるにつれ， キニジン型 $\mathrm{I}_{\mathrm{Kr}}$ 遮断やドフェチリド型 $\mathrm{I}_{\mathrm{Kr}}$ 遮断はさら 128

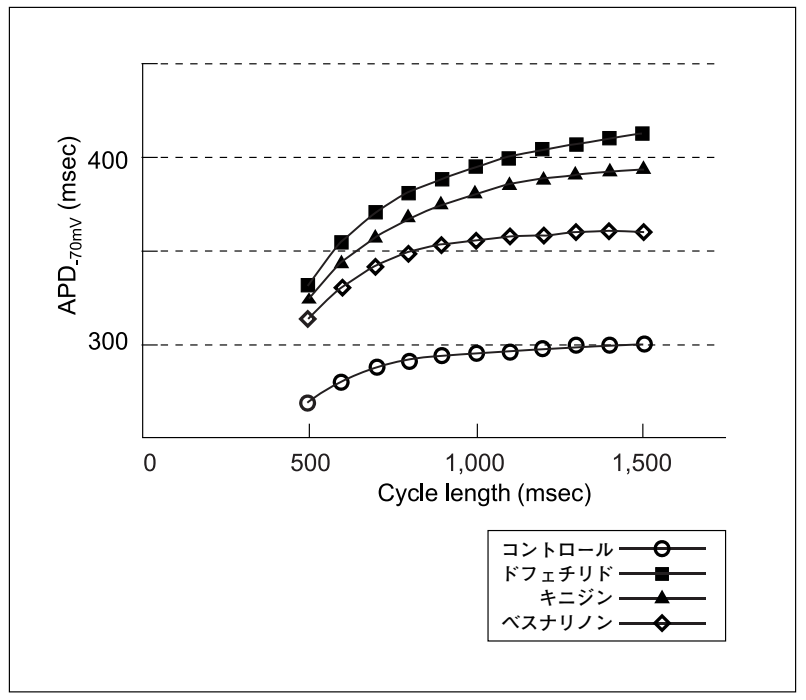

図2 $\mathrm{I}_{\mathrm{kr}}$ 遮断によるヒト心房筋細胞モデルの活動 電位の延長

$\mathrm{I}_{\mathrm{Ks}}$ を修正したヒト心房筋細胞モデルを使用し，刺激周期を変 化させ, 各 $\mathrm{I}_{\mathrm{Kr}}$ 遮断型下での $-70 \mathrm{mV}$ による活動電位長を計 算した.

〔文献1)より引用改変〕

に活動電位を延長する (逆頻度依存性の活動電位延 長) が，ベスナリノン型 $\mathrm{I}_{\mathrm{Kr}}$ 遮断では延長効果が弱い. この違いは $\mathrm{I}_{\mathrm{Kr}}$ 遮断挙動の違いによって説明できる。 ドフェチリド型の $\mathrm{I}_{\mathrm{Kr}}$ 遮断は刺激周期にかかわらず常 に一定であるが，キニジン型やベスナリノン型では 電位に依存して $\mathrm{I}_{\mathrm{Kr}}$ 遮断が変化する. 活動電位発生に 伴う脱分極により $\mathrm{I}_{\mathrm{Kr}}$ 遮断は強くなり, 活動電位終了 後の静止膜電位で $\mathrm{I}_{\mathrm{Kr}}$ 遮断は次の活動電位の直前まで 回復する．刺激周期が延びるにつれ，キニジン型と ベスナリノン型の $\mathrm{I}_{\mathrm{Kr}}$ 遮断の回復の度合いは大きくな る。そのため, 活動電位が発生した時点での $\mathrm{I}_{\mathrm{Kr}}$ 遮断 は刺激周期に依存している。しかし，キニジン型 $\mathrm{I}_{\mathrm{Kr}}$ 遮断に関しては, 活動電位中の遮断の進行が速いた め, 刺激周期に関係なく活動電位中に強い $\mathrm{I}_{\mathrm{Kr}}$ 遮断が 実現される。そのため，キニジン型 $\mathrm{I}_{\mathrm{Kr}}$ 遮断はドフェ チリド型と同様に逆頻度依存性の活動電位延長を示 すことになった。一方，ベスナリノン型 $\mathrm{I}_{\mathrm{Kr}}$ 遮断では， 活動電位中の $\mathrm{I}_{\mathrm{Kr}}$ 遮断は刺激周期に依存し, 刺激周期 が延長するにつれ $\mathrm{I}_{\mathrm{Kr}}$ 遮断効果が弱くなり, 逆頻度依 存性が低くなった。以上のような解析を実験的に行 


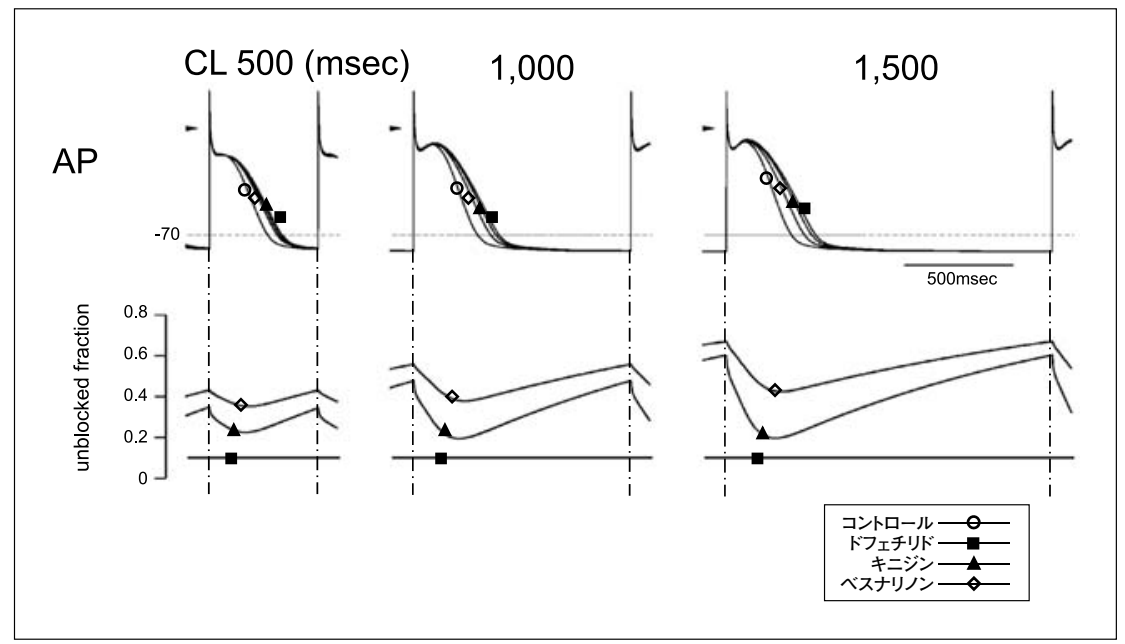

図3

異なる刺激周期での $\mathrm{I}_{\mathrm{kr}}$ 遮断効果

異なる刺激周期でのコントロールお よび各種 $\mathrm{I}_{\mathrm{Kr}}$ 遮断型下での活動電位

（上）と $\mathrm{I}_{\mathrm{Kr}}$ 遮断の時間変化.

〔文献1)上り引用改変〕

うことは不可能であるため，こうした作用機序の解 明を行えることは，モデル研究の大きな利点である と考えられる.

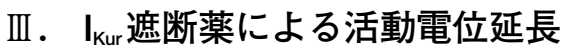

近年，AFを対象とする新規抗不整脈薬の機序と して， $I_{\text {Kur }}$ が注目を集めている． $I_{\text {Kur }}$ は Kv1.5で構成 されるチャネル電流で，ヒト心房筋細胞において活 動電位の再分極に寄与する．実験的に $\mathrm{I}_{\mathrm{Kur}}$ はヒト心 室においてほとんど検出されないため，選択的 $\mathrm{I}_{\mathrm{Kur}}$ 遮断薬はほかの $\mathrm{K}^{+}$チャネル遮断薬と異なり, 心室 において TdPのような不整脈を起こさないと期待さ れている. そのため, 現在, 多数の $\mathrm{I}_{\mathrm{Ku}}$ 遮断薬が開 発中である。しかし，これらの $\mathrm{I}_{\mathrm{Ku}}$ 遮断薬は，不応 期延長，頻度依存性といった面で，抗不整脈薬とし て多様な特性をもっている。この特性の違いによる 理由の一つとして， $\mathrm{I}_{\mathrm{Kur}}$ 遮断薬は実験的に様々な電位 時間依存性を示すことがあげられ，各 $\mathrm{I}_{\mathrm{Kur}}$ 遮断薬が 活動電位に対して現実には異なる作用をもつ可能性 が考えられる。

異なる様々な特性のなかから， $\mathrm{I}_{\mathrm{Kur}}$ 遮断薬が抗不整 脈薬としてどのような特性をもつべきかを考察する ため，同じヒト心房筋細胞モデルに電位時間依存性 の $\mathrm{I}_{\mathrm{Ku}}$ 遮断を導入した。この検討では電気的リモデ リングを経たヒト心房筋細胞モデルも使用した。 AFでは，慢性的な細動が心房の電気生理的性質に
変化を生じさせる，いわゆる電気的リモデリングと よばれる現象が問題となっている。この電気的リモ デリングにより活動電位と不応期が短縮し，AFが 発生・持続されやすくなる。この検討では，慢性 $\mathrm{AF}$ のヒト心房筋細胞モデルで電位時間依存性の $\mathrm{I}_{\mathrm{Kur}}$ 遮断薬の活動電位延長効果をシミュレーションし た。慢性 AFにおける電気的リモデリングは，実験 的な知見に基づいて各電流の最大コンダクタンスを 変化させることで実現した。

通常のヒト心房筋細胞と電気的リモデリングを経 たヒト心房筋細胞で検討を行うために，各モデルの $\mathrm{I}_{\mathrm{Kur}}$ を電位時間非依存的に遮断した（図4). $\mathrm{I}_{\mathrm{Kur}}$ 遮断 に伴い，通常の心房筋細胞モデルの活動電位では 2 相のふくらみが脱分極側に増幅したが， $-70 \mathrm{mV}$ 計算された活動電位長に大きな変化は生じなかった (図4 Normal)。一方，電気的リモデリングを考慮し た心房筋細胞モデルでは活動電位が延長した。これ は実験による知見や過去のモデル研究と一致し ${ }^{6}$, $\mathrm{I}_{\mathrm{Kur}}$ 遮断薬が慢性 $\mathrm{AF}$ を対象とした抗不整脈薬として 高い可能性をもっていることを示している，以後， 電気的リモデリングを経た心房筋細胞モデルのみを 対象に解析を行った。

次に, 同じモデルを使用し, 電位時間依存性 $\mathrm{I}_{\mathrm{Kur}}$ 遮断を導入した(図5). $\mathrm{I}_{\mathrm{Kur}}$ 遮断の大きさを $90 \%$ に固 定し， $\mathrm{I}_{\mathrm{Kur}}$ 遮断の立ち上がりの時間定数を変化させた ところ, 最も小さい時間定数 $(=$ 速い遮断の立ち上 


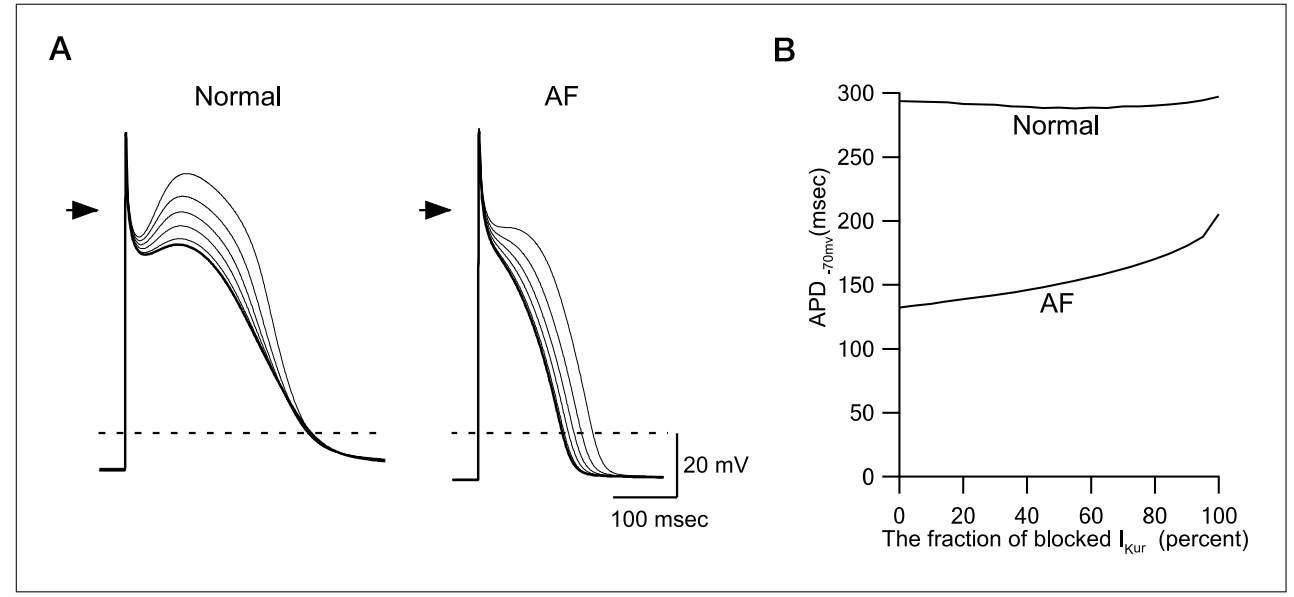

図4 電位時間非依存性 $I_{K u r}$ 遮断による活動電位の延長作用

A ： $\mathrm{I}_{\mathrm{Kur}}$ の最大コンダクタンスを段階的に減らしたときの通常のヒト心房筋細胞モデル (Normal)

と, 電気的リモデリングを経たヒト心房筋細胞モデル $(\mathrm{AF})$ での活動電位の変化.

$B$ ：活動電位長と $\mathrm{I}_{\mathrm{Kur}}$ 遮断強度との相関関係.

〔文献2)より引用改変〕

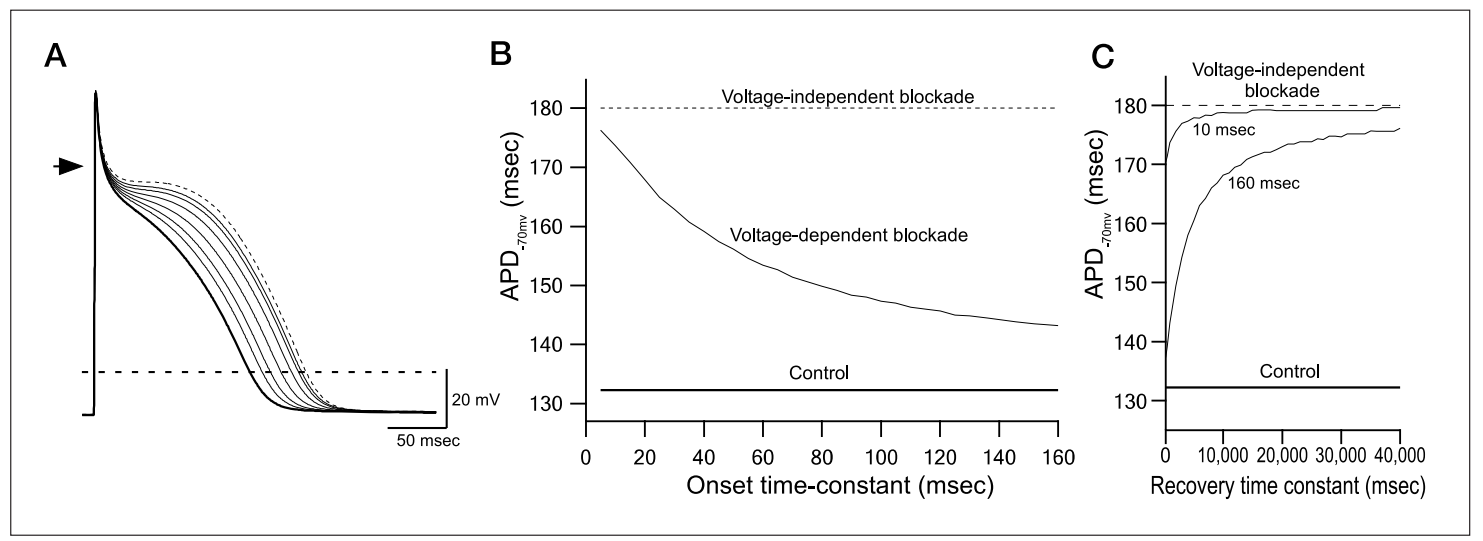

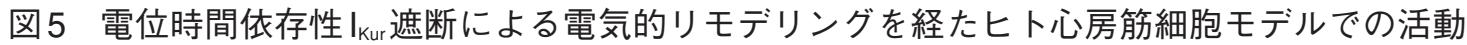
電位の延長作用

$\mathrm{A} ： \mathrm{I}_{\mathrm{Kur}}$ 遮断の立ち上がりの速さ(左より時間定数 $5 \mathrm{msec}, 10 \mathrm{msec}, 20 \mathrm{msec}, 40 \mathrm{msec}, 80 \mathrm{msec}, 160 \mathrm{msec}$ )が活 動電位長に与える影響。太線はコントロール，点線は電位時間非依存性 $\mathrm{I}_{\mathrm{Kur}}$ 遮断の結果.

$\mathrm{B}$ ：活動電位長と $\mathrm{I}_{\mathrm{Ku}}$ 遮断の立ち上がりの時間定数との関係.

$\mathrm{C}$ ：立ち上がりの時間定数を $10 \mathrm{msec}$ と $160 \mathrm{msec}$ に設定したときの， $\mathrm{I}_{\mathrm{Ku}}$ 遮断の回復の時間定数と活動電位長 の関係.

〔文献2)より引用改変〕

がり)にて活動電位は最も延長した(図 5A，B)。一 方，立ち上がりの時間定数を $10 \mathrm{msec} に$ 固定し，回 復の時間定数を変化させた場合には，活動電位長に 対する影響がほとんど認められなかった（図 5C). しかし，立ち上がりを遅く(時間定数 $160 \mathrm{msec}$ ) 設定 し，回復を遅く(時間定数を大きく)するに従い活動
電位が延長した。これらの特性の違いは $\mathrm{I}_{\mathrm{Kr}}$ 遮断と同 様に，遮断の進行，回復によって説明することがで きる(詳細は文献 2 参照).

では，このような特性をもった薬物をスクリーニ ングする際にはどのような手法を用いるべきであろ うか？ 例えば，in vitroの $\mathrm{K}^{+}$チャネル遮断薬のスク 


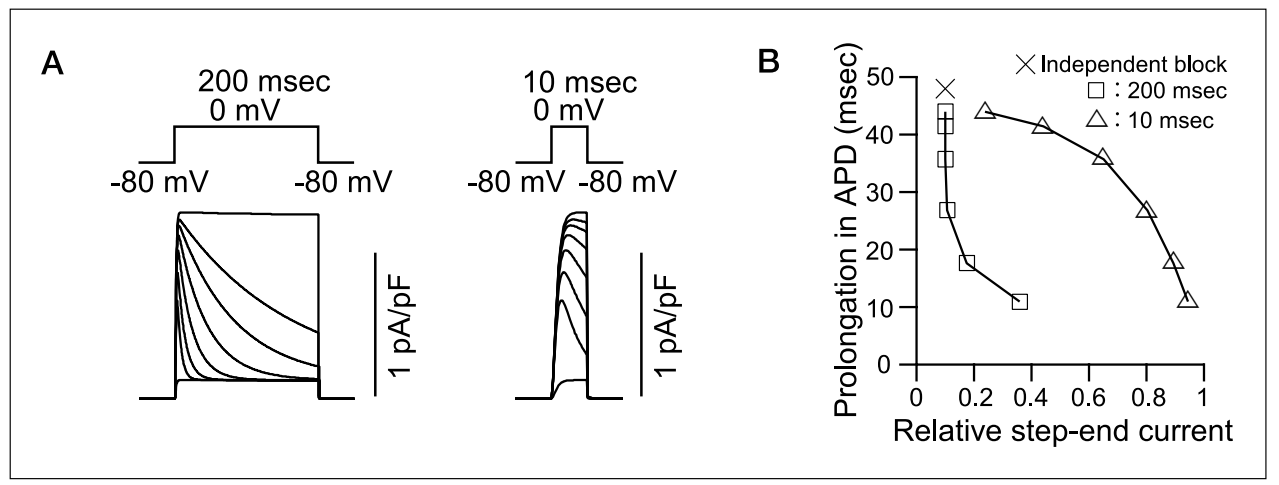

図 6 ボルテージクランプにおける $\mathrm{K}_{\mathrm{kur}}$ シミュレーション

$\mathrm{A} ：-80 \mathrm{mV} \sim 0 \mathrm{mV}$ パルスを加えたときの電位時間依存性 $\mathrm{I}_{\mathrm{Ku}}$ 庶断下での $\mathrm{I}_{\mathrm{Kur}}$ 電流. 下から上へ, 電位時間非依存 $\mathrm{I}_{\mathrm{Ku}}$ 遮断, 電位時間依存 $\mathrm{I}_{\mathrm{Ku}}$ 遮断 (時間定数 $5 \mathrm{msec}, 10 \mathrm{msec}, 20 \mathrm{msec}$, $40 \mathrm{msec}, 80 \mathrm{msec}, 160 \mathrm{msec})$, コントロール.

$\mathrm{B}$ ：パルス終了時の $\mathrm{I}_{\mathrm{Kur}}$ 電流量と予測される活動電位延長の関係。【文献2)より引用改変〕

リーニングの場合，イオンチャネル発現系を用いた パッチクランプ法での遮断効果の確認が行われてい る.しかし，電位固定パルスを用いたパッチクラン プでの電流遮断の挙動と, 実際の活動電位での挙動 は大きく異なっている可能性が高い。そこでわれわ れは，どのようなパッチクランプのプロトコルが活 動電位中の $\mathrm{I}_{\mathrm{Kur}}$ 遮断薬の効果を探るのに適している かを考察した，例えば，図6は200 msecという一般 によく使われる長さのパルス長を利用した $\mathrm{I}_{\mathrm{Kur}}$ 電流 のシミュレーション結果である．立ち上がりの時間 定数を変えてシミュレーションしたところ, $\mathrm{I}_{\mathrm{Kur}}$ 遮断が パルス中にほほ進行し終わることがわかる(図6A左). そのため, このパルス長とパルス終了時の電流では, $\mathrm{I}_{\mathrm{Kur}}$ 遮断の立ち上がりの速さの影響を推測することが 難しいとわかる．さらに，立ち上がりの時間定数を 変化させて活動電位のシミュレーションを行い, 図6B(四角)のように $200 \mathrm{msec}$ のパルス終了時の電 流と活動電位延長の関係をグラフにすると, 相関関 係が取りにくく, パルス終了時の電流から活動電位 延長効果が推量できないことがわかる.これに対し て，10 msecという短いパルス長を用いたプロトコ ルのシミュレーションでは, 遮断の立ち上がりをス テップ終了時の電流で捉えることができ(図6A右), パルス終了時の電流から活動電位延長の度合いが
予測可能である。これらの結果は，ステップの長さ を注意深く選ぶことにより電位時間依存性遮断の薬 物効果を予測できることを示唆している，例えば， 遮断の回復についてもヒト心房筋細胞の活動電位長 に近い長さのパルスを繰り返し加えた後に, 短いパル スを加えることにより予測が可能になる2).

\section{IV. 考察}

本研究では以下のようなことが明らかになった. (1) $\mathrm{I}_{\mathrm{Ks}}$ に遅い活性化成分を導入することで $\mathrm{I}_{\mathrm{Kr}}$ 遮断時 の逆頻度依存性を再現できること，(2)異なる薬物動 態をもつ三つの薬物型 $\mathrm{I}_{\mathrm{Kr}}$ 遮断の効果を説明できるこ と, (3) $\mathrm{I}_{\mathrm{Kur}}$ 遮断薬の効果を検討する際には電位時間 依存性を考慮する必要があること，(4)そのスクリーニ ングにはパルス幅の短いプロトコルが有効であること.

現在の薬物開発における大きな課題の一つとし て, 多数の薬物が心筋の $\mathrm{I}_{\mathrm{Kr}}$ を遮断し, 逆頻度依存的 に活動電位を延長するため，TdPのような不整脈を 引き起こすことがあげられる．この副作用のために 多数の薬物が市場から撤退もしくは使用が制限さ れ，ほかにも多数の潜在的な候補薬物が，市場に出 る前に開発を止められている。こうしたリスクの評 価・予測方法の一つとして本研究で用いたようなモ デル研究があげられる. 
本研究では Courtemancheらによるヒト心房筋細 胞モデルを使用したが，彼らのオリジナルのモデル では $\mathrm{I}_{\mathrm{Kr}}$ 遮断下での逆頻度依存性が再現できない. そ こでわれわれは， $\mathrm{I}_{\mathrm{Ks}}$ に修正を加えることで逆頻度依 存性を再現できるように改良した。ささらに，発現系 を用いた研究において， $I_{\mathrm{Ks}}$ にはさらに遅い成分が存 在する可能性が示唆されている。このような遅い $\mathrm{I}_{\mathrm{Ks}}$ 成分をモデルに取り入れれば，さらに逆頻度依存性 が明確になると考えられ，逆頻度依存性の機序とい う観点からも， $\mathrm{I}_{\mathrm{Ks}}$ のさらなる研究の重要性があると 推測される。

慢性 AF 患者からの単離心房筋細胞の活動電位長 は, 通常のものと比べて短いことが知られている. これは $\mathrm{I}_{\mathrm{CaL}}, \mathrm{I}_{\mathrm{t}}, \mathrm{I}_{\mathrm{Kur}}, \mathrm{I}_{\mathrm{K} 1}$ などの量が変化する電気的 リモデリングによる. Courtemancheらはこの変化 をモデルに導入することで，慢性 AF 患者での薬物 効果の可能性を考察した ${ }^{6)}$. 本研究ではさらに $\mathrm{I}_{\mathrm{Kur}}$ 遮 断の電位時間依存性を考慮することで，理想的な 薬物像とそのスクリーニング方法を検討した。考察 により，慢性の $\mathrm{AF}$ に有効な $\mathrm{I}_{\mathrm{Kur}}$ 遮断は速い立ち上が り，もしくは，遅い回復という特性をもっていると 予測された。こうした観点はいままで考慮されてい なかったが，実際に有効であるとされる $\mathrm{I}_{\mathrm{Kur}}$ 遮断薬 （例えばAVE0118など）はこの予測されたプロファ イルに一致している。さらに今回の研究では長いパ ルス長によると $\mathrm{I}_{\mathrm{Kur}}$ 遮断薬の不整脈薬としての特性 を捉えきれない可能性を示唆したが，従来のin vitroの実験では， $\mathrm{I}_{\mathrm{Kur}}$ 遮断を強調するために長いパ ルス長が使用されてきた。そのため，過去のスクリー ニングが効率的でなかった可能性がある.

ここで使われているように，in silicoのアプロー チを使うことで，in vitroの結果を再現できるだけ でなく，予測や効率化さえも可能になる．実際問題 として in silicoのアプローチが in vitroや in vivoをす べて代用するということは考えられにくいが，目的 とする効果をもつ薬物の検証のために必要とされる 実験の数を減らすことができると考えられる，例え ば，単離ヒト心房筋細胞の入手は非常に難しく, in vitroに用いることができるサンプルは量・質ともに 限られている．慢性 AF の単離ヒト心房筋細胞とな ると入手の状況はさらに悪くなる. そういった意味 で, 今回予測されたプロファイルに属していない薬 物を排除することにより，薬物開発の効率化が図れ るのではないかと考えられる。

\section{V.おわりに}

本研究はヒト心房筋細胞モデルを使用したもので あるが，現在ヒト心房以外にも，各種動物の心臓の いろいろな部位を用いた心筋細胞モデルが存在して いる．完壁なモデルは存在しないが，目的に適した モデルを適切に選ぶことによって, 本研究のように 再現のみならず，薬物像の予測を行い，開発の効率 化を図ることができるのではないかと考えられる.

\section{〔文献〕}

1) Tsujimae K, Suzuki S, Murakami S, Kurachi Y : Frequency-dependent effects of various IKr blockers on cardiac action potential duration in a human atrial model. Am J Physiol Heart Circ Physiol, 2007 ; 293 : $\mathrm{H} 660 \sim \mathrm{H} 669$

2 ) Tsujimae K, Murakami S, Kurachi Y : In silico study on the effects of IKur block kinetics on prolongation of human action potential after atrial fibrillation-induced electrical remodeling. Am J Physiol Heart Circ Physiol, $2008 ; 294:$ H793 H800

3 ) Katayama Y, Fujita A, Ohe T, Findlay I, Kurachi Y : Inhibitory effects of vesnarinone on cloned cardiac delayed rectifier $\mathrm{K}^{+}$channels expressed in a mammalian cell line. J Pharmacol Exp Ther, 2000 ; 294 : $339 \sim 346$

4 ) Tsujimae K, Suzuki S, Yamada M, Kurachi Y : Comparison of kinetic properties of quinidine and dofetilide block of HERG channels. Eur J Pharmacol, $2004 ; 493$ : 29 40

5 ) Courtemanche M, Ramirez RJ, Nattel S : Ionic mechanisms underlying human atrial action potential properties : insights from a mathematical model. Am J Physiol, 1998 ; 275 : H301 H321

6 ) Courtemanche M, Ramirez RJ, Nattel S : Ionic targets for drug therapy and atrial fibrillation-induced electrical remodeling : insights from a mathematical model. Cardiovasc Res, $1999 ; 42: 477 \sim 489$ 